\title{
36. LATE MIOCENE PALEOENVIRONMENTS AND TECTONIC SETTING OF THE SOUTHERN MARGIN OF CYPRUS AND THE ERATOSTHENES SEAMOUNT ${ }^{1}$
}

\author{
Alastair H.F. Robertson ${ }^{2}$
}

\begin{abstract}
During drilling of Leg 160 in the Eastern Mediterranean (April-May, 1995), Messinian (i.e., uppermost Miocene) facies were identified at a site at the base of the Cyprus slope (Site 968) and at two sites on the Eratosthenes Seamount (Sites 965 and 967). The new results can be compared with the recovery of Messinian evaporites from the Florence Rise west of Cyprus (Deep Sea Drilling Project Sites 375 and 376), with onshore southern Cyprus, and with other Mediterranean basins. The Messinian at Site 968 is dominated by dark, anoxic muds and minor turbiditic silts and sands that contain grains of pelagic limestone, chert, and ophiolitic rocks, all derived from onshore southern Cyprus. Minor intercalations of fine- to rarely coarse-grained gypsum show evidence of gravity reworking. At Site 967, on the lower southern slopes of the Eratosthenes Seamount, the existence of a thin $(<5 \mathrm{~m})$ interval of gypsum was inferred from both geophysical logging and pore-water geochemical studies. Postcruise studies have led to the recognition of an important Messinian/Pliocene boundary interval in Hole 967A, with accumulation of brackish water, Lago Mare-type sediments containing ostracods. A thin unit (approximately $6 \mathrm{~m}$ ) of Messinian paleosols and caliche was recovered at Site 955 on the upper slopes of the seamount. On the crestal area of the seamount at Site 966, Messinian is absent, and lower Pliocene sediment rests unconformably on diagenetically altered Miocene shallow-water limestone.

A terrigenous-dominated succession at Site 968 at the base of the Cyprus slope resembles the upper Messinian interval cored on the Florence Rise west of Cyprus (Sites 375 and 376). Both areas lie on the trend of the Cyprus active margin that accommodates convergence of the Eurasian and African Plates. The Eratosthenes Seamount was already a raised feature in the Miocene, above the level of Messinian evaporite precipitation. The northern upper slope area (Site 965) and the seamount plateau area then formed part of a laterally extensive carbonate platform, followed by breakup and subsidence in Pliocene-Pleistocene time. However, the northern lower slope area (Site 967) lay beyond the area of shallow-water carbonate deposition in the Miocene and continued to accumulate pelagic carbonates, as recorded by Eocene, Oligocene, and Miocene planktonic biota that were reworked within chalky debris flows before the Messinian. Thin Messinian gypsum $(<5 \mathrm{~m})$ then accumulated, possibly under fault control, followed by marine transgression, with accumulation of laminated ooze containing ferruginous oxide. Overall, the late Miocene-early Pliocene paleoenvironments document the subduction and initial states of breakup of the Eratosthenes Seamount as it began to collide with Cyprus active margin to the north.
\end{abstract}

\section{INTRODUCTION}

The concept of at least partial desiccation of the Mediterranean Sea (Hsü et al., 1973; 1978) in the upper Miocene (Messinian) has now received almost universal acceptance. Recently it has become clear that, in addition to regional sea-level fall within the Mediterranean, more local tectonic processes have played an important role in influencing the accumulation of evaporites and related sediments. Early deep-sea drilling of widely spaced sites in the Mediterranean during Deep Sea Drilling Project (DSDP) Leg 13 (Ryan, Hsü, et al., 1973) and Leg 42A (Hsü, Montadert, et al., 1978) provided much information on evaporite facies, but left open many questions concerning the specific depositional and tectonic settings. The plate tectonic setting of the Mediterranean was then poorly understood, particularly the role of the Mediterranean Ridge and the Cyprus active margin as parts of the plate boundary between the African and Eurasian Plates. More information on shallow-water Messinian evaporites exposed on land around the Mediterranean basin has recently become available and can now be integrated with the drilling results (e.g., Rouchy and Saint Martin, 1992). The purpose of this paper is to compare evidence of Messinian paleoenvironments from sites drilled across the Eratosthenes Seamount (Sites 966, 965, and 967) and on the lower slope

${ }^{1}$ Robertson, A.H.F., Emeis, K.-C., Richter, C., and Camerlenghi, A. (Eds.), 1998. Proc. ODP, Sci. Results, 160: College Station, TX (Ocean Drilling Program).

${ }^{2}$ University of Edinburgh, Department of Geology and Geophysics, West Mains Road, Edinburgh, EH9 3JW, United Kingdom. Alastair.Robertson@glg.ed.ac.uk of the Cyprus margin (Site 968) with information obtained from DSDP Leg 42A on the Florence Rise to the northwest and also from onshore southern Cyprus (Fig. 1). This comparison gives a more complete picture of the depositional processes and the paleotectonic setting of the Eastern Mediterranean during the late Miocene to earliest Pliocene.

\section{RESULTS OF DRILLING}

\section{Site 968: Lowermost Cyprus Slope}

By far the thickest inferred Messinian succession $(\sim 136 \mathrm{~m})$ cored during Leg 160 was recovered from Site 968, located on a small north-south-trending ridge near the foot of the southern slope of the Cyprus margin, adjacent to a deep basin that separates Cyprus from the Eratosthenes Seamount to the south (Fig. 2). A Messinian age for the lower about $136 \mathrm{~m}$ of the succession cored at this site was inferred by the Shipboard Scientific Party (Emeis, Robertson, and Richter, et al., 1996; Robertson et al., 1995b, 1995c), based on the presence of exclusively reworked planktonic foraminifers and nannofossils below a well-dated lower Pliocene succession. This succession contains a typical brackish water Lago Mare-type assemblage of Cyprides pannonia and Ammonium tepida (below 190 meters below seafloor [mbsf]; Pierre et al., Chap. 1, this volume).

The lower part of the succession cored at Site 968 is highly disturbed, and was recovered mainly as drilling biscuits (Cores 160968-24X through 28X). Throughout the succession, colors are main-

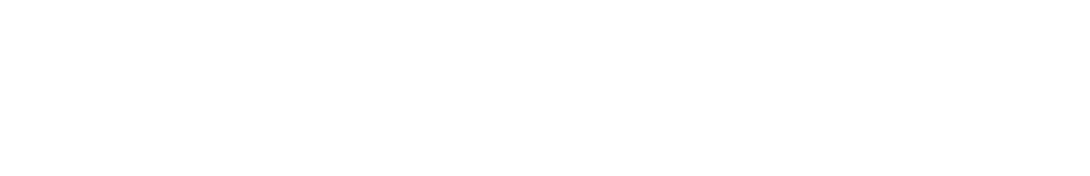




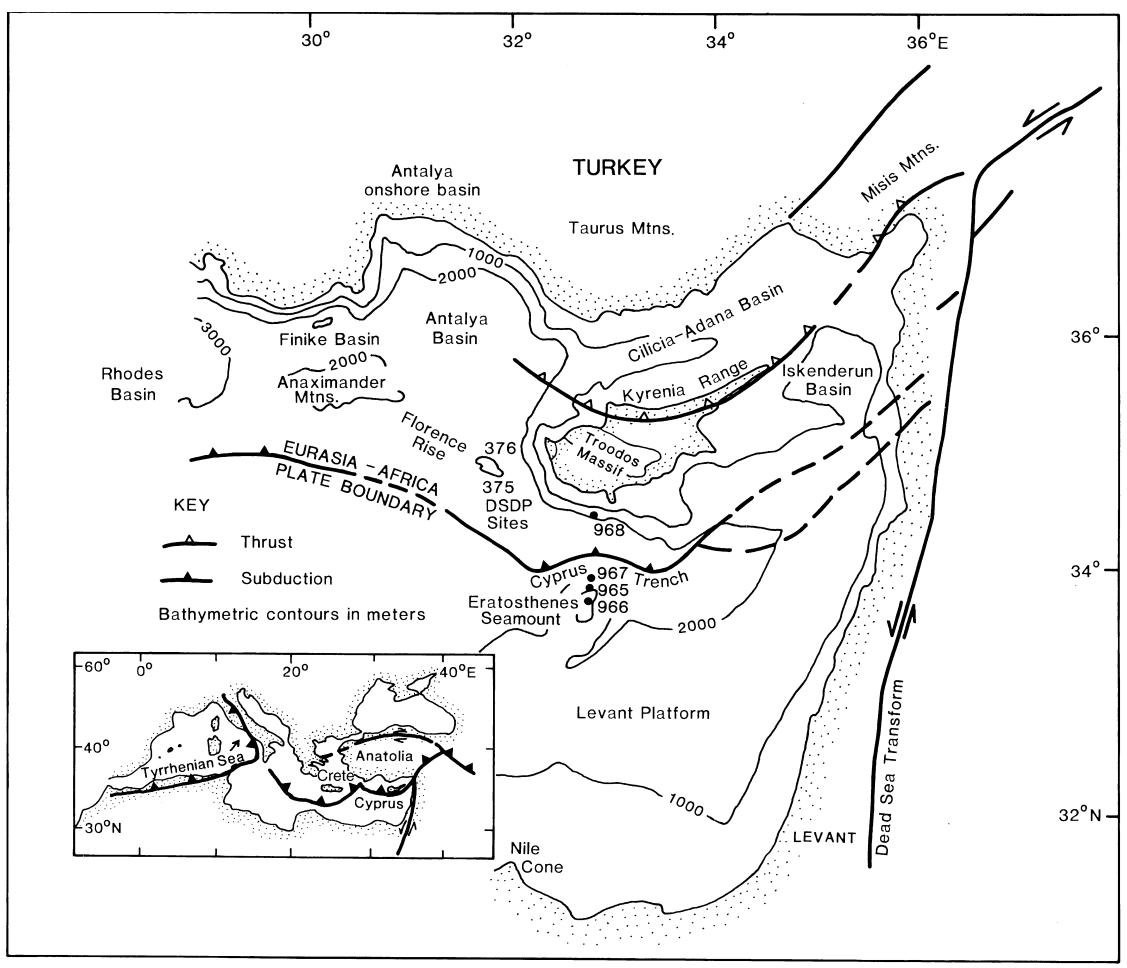

Figure 1. Tectonic setting of the Eratosthenes Seamount in the Eastern Mediterranean showing the inferred location of the present-day Cyprus active margin. Locations of Sites 965, 966, 967, and 968 are shown. Note also the location of DSDP Sites 375 and 376 west of Cyprus.

ly subdued (e.g., dark gray, greenish gray), but rare thin horizons of a redder color occur (e.g., a "red bed" in Section 160-968A-24X-3). Burrowing is minimal, and it is inferred that background accumulation mainly took place under reducing conditions. However, some intervals exhibit orange staining and orange mottling (Core 160-966A$23 \mathrm{X})$ suggestive of locally more oxidizing conditions. $3)$.

The main lithofacies are described in the following sections (Fig.

\section{Calcareous Clays and Muddy Clays}

These are barren of microfossils (except where reworked) and are interbedded with silts and sands throughout the lower part of the succession cored (e.g., Core 160-968A-28X). The clay is commonly uniform in color, but faint color banding is locally observed (Core 160968A-21X). Some clays are relatively silty (e.g., Core 160-968A25X).

Much of the lower part of the succession recovered is composed of structureless, poorly consolidated muds and calcareous clays, again of subdued color. In some intervals (e.g., Core 160-968A-32X) thin $(<5 \mathrm{~cm}$ thick) horizons contain a higher sand content.

\section{Silt}

Discrete intervals of silt are present mainly toward the base of the succession (Fig. 4). For example, dark muds are interbedded with 5to $10-\mathrm{cm}$-thick intervals characterized by dark silty intervals at the base of individual depositional units (e.g., Core 160-968A-26X). Also, fining-upward depositional units are seen higher in the succession (Core 160-968A-19X). The bases of such individual units are slightly erosive into muds beneath (e.g., Core 160-968A-18X). Other intervals are nearly massive (e.g., Section 160-968A-22X-1). Some indi- vidual silty beds are topped by white laminae, of which up to four were observed above a single silt bed (Section 160-968A-18X-3).

\section{Sand}

In the lower part of the succession, discrete intervals of sand alternate with mud and clay. Where they have locally escaped drilling disturbance, the sands exhibit sharp bases and gradational tops, suggestive of an origin as turbidites (e.g., Sections 160-968A-30X-1 through 2, and 160-968A-29X-1 through 4). Where less disturbed by drilling, fine-grained sands are seen to alternate with calcareous clays on a scale of approximately $30-60 \mathrm{~cm}$.

\section{Gypsum}

Gypsum first appears near the base of the succession as rare partings up to 1-2 cm thick, within alternations of fine sandy clay and clayey sand (e.g., Cores 160-968A-28X and 27X). Slightly higher in the succession (Core 160-968A-26X), occasional beds are composed of coarse gypsum, together with sand-sized detrital grains (Figs. 4, 5). This gypsum material appears to be mainly detrital (i.e., "gypsarenite"). Overlying interbeds of gypsum-rich silt are up to $9 \mathrm{~cm}$ thick and are interbedded with green silty clays. In addition, a rare thin $(17 \mathrm{~cm})$ interval is composed of microcrystalline (i.e., alabastrine) gypsum, including some green clay particles. Shipboard observations suggested that some of this gypsum could be in situ (Emeis, Robertson, Richter, et al., 1996).

\section{Petrography and Mineralogy}

Twelve impregnated thin sections were studied to shed light on the origin of the sand-sized fraction at Site 968. The samples from the post-Miocene succession are dominated by reworked pelagic carbon- 


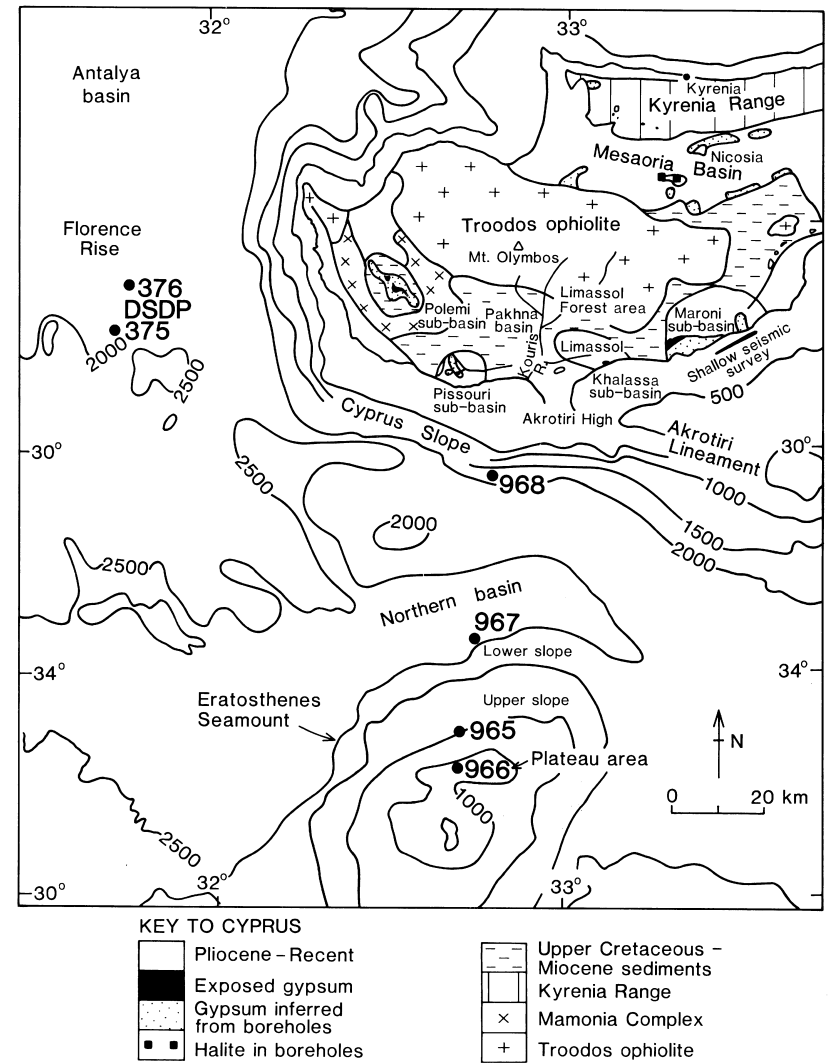

Figure 2. Outline map showing the Eratosthenes Seamount in relation to the onshore geology of southern Cyprus. Sites 965, 966, 967, and 968 are also indicated. Note the occurrences of Messinian evaporites onshore. Much of the terrigenous sediment in the vicinity of Site 978 was probably supplied through the Kouris river system.

ate and planktonic foraminifers, with variable quantities of volcanic glass (mainly green but locally brown), biotite, and shell fragments, together with small amounts of angular quartzose silt, plagioclase, hornblende, pyroxene, and chlorite. The provenance was mainly from airfall tuff with a minor terrigenous component.

In strong contrast, the samples from the Messinian interval contain abundant, coarser grained lithoclastic silt that was clearly mainly derived from the Troodos ophiolite of Cyprus and its sedimentary cover. Common lithoclasts, which are mainly moderately to well rounded, are basalt, pelagic chalk, chert, serpentinite, diabase, and gabbro, and rare recrystallized limestone, in decreasing order of abundance. Individual crystals include quartz, biotite, plagioclase (also rare exsolved feldspar), muscovite, chlorite, pyroxene, hornblende, opaque iron oxide, and pyrite. The basalt is mainly moderately to highly altered. Quartz grains are subrounded to rounded, clear, but with undulose extinction. Feldspar crystals are mainly strongly altered. Chert ranges from finely crystalline microcrystalline quartz to more coarsely crystalline drusy quartz. Rare reddish chert is composed of opal-CT (i.e., isotropic silica). In addition, occasional small (i.e., mm sized) lithoclasts of cleaved mica schist and rare mediumgrained quartzose sandstone are present. Bioclasts are mainly reworked planktonic foraminifers and some shell fragments.

The Messinian clastic sediment was derived from all levels of the Troodos ophiolite and its sedimentary cover. The sedimentary cover lithology is mainly pelagic chalk correlated with the Maastrichtian to Oligocene Lefkara Formation and the Miocene Pakhna Formation. The chert is typical of the replacement chert within the Lefkara Formation (Robertson, 1977). The reddish chert with isotropic silica is
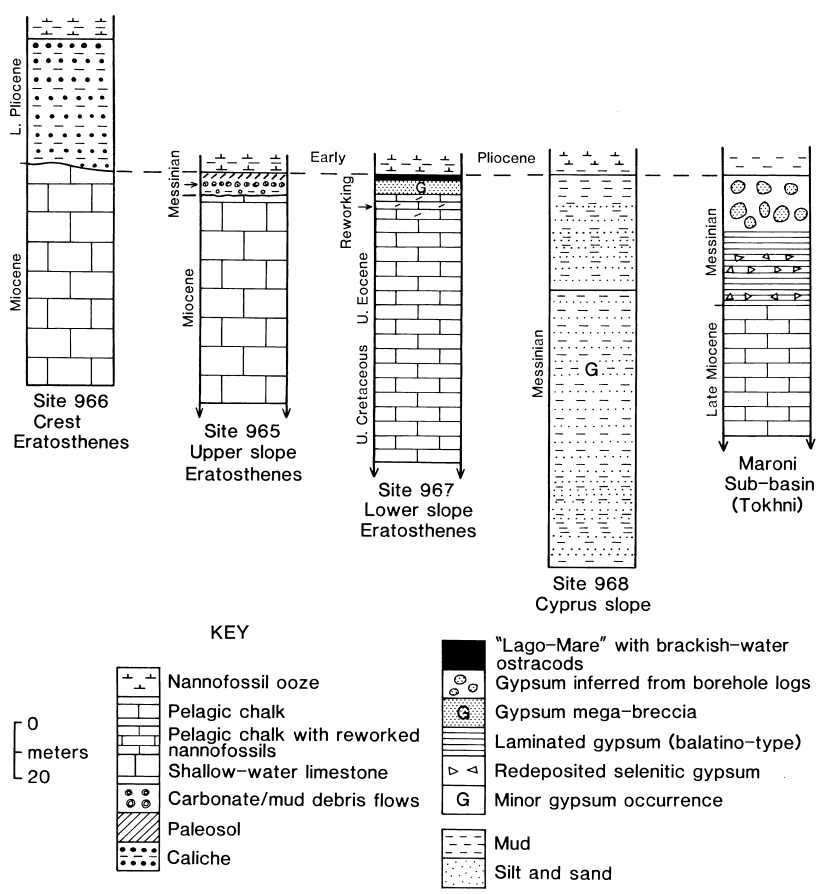

Figure 3. Logs summarizing the Messinian of Sites 965, 966, 967, and 968. Note that postcruise studies have identified an intact Messinian/Pliocene boundary succession at Site 967 .
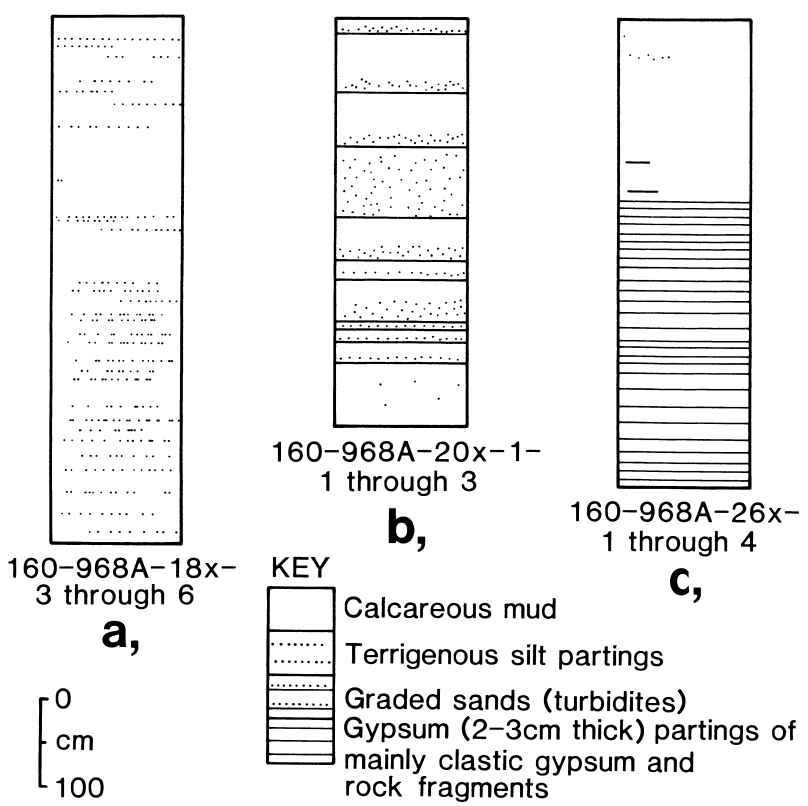

Figure 4. Detail of parts of the inferred Messinian succession at Site 968. A. Silt partings. B. Thin graded silts, interpreted as low-density turbidites. C. Clastic gypsum partings.

characteristic of the Campanian Perapedhi Formation. The ophiolitic material is dominated by altered lava. The serpentinite and plutonic rocks could have been derived either from the main Troodos ophiolite, or from the Limassol Forest ophiolite further south. Evidence from the Pliocene-Pleistocene sedimentary cover of the ophiolite shows that serpentinite was exposed to erosion in Pleistocene time. During the Miocene ophiolitic rocks in the Limassol Forest area of 
A

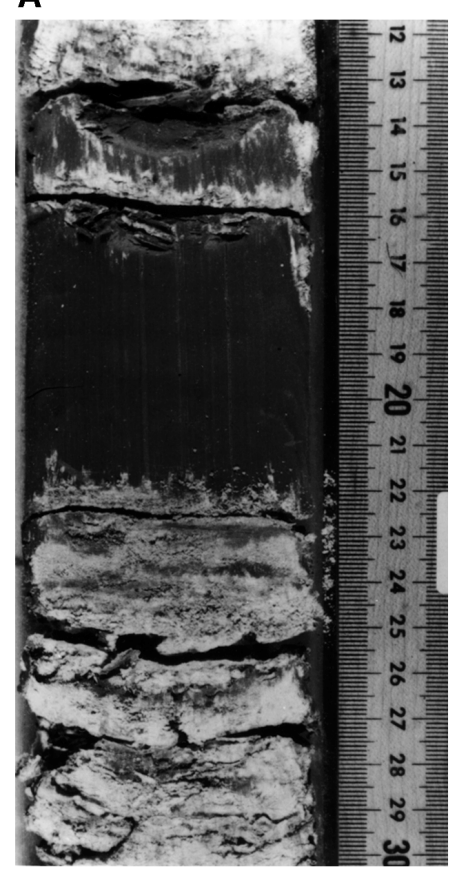

B

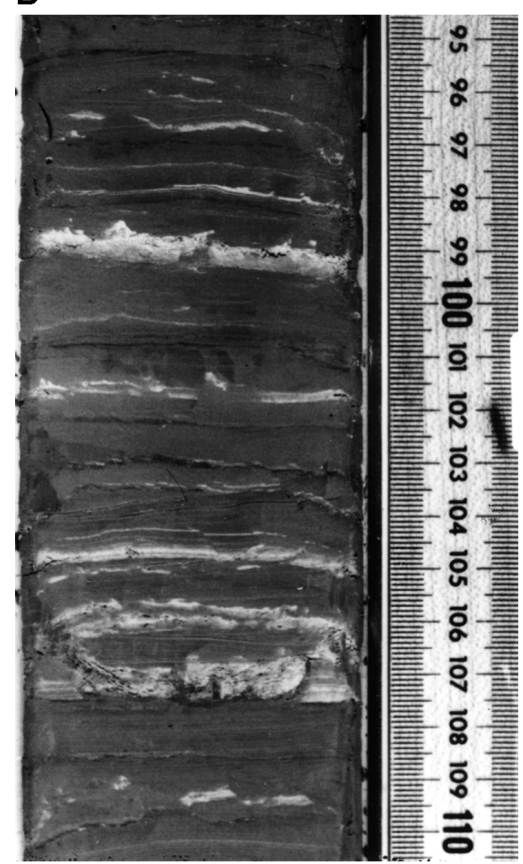

Figure 5. Core photographs of the Messinian in Hole 968A. A. Thin layers of redeposited calcareous silt mainly derived from the Troodos Massif to the north (interval 160-968A-25X-CC, 12-30 cm). B. Massive mud interbedded with reworked gypsum (i.e., gypsarenite; interval 160-968A-26X-2, 95-110 cm).

southern Cyprus were deformed by thrusting and locally eroded to provide material to the onshore stratigraphic record of the Pakhna Formation. However, this material does not include serpentinite, presumably because ophiolitic rocks of the Limassol Forest area were not then eroded sufficiently deeply to expose ultramafic rocks (Robertson et al., 1991). The rare sandstone and schist could also have come from the allochthonous Mesozoic rocks of the Moni Melange and Mamonia Complex, exposed in southern and southwestern Cyprus, respectively. The well-rounded nature of many of the lithoclastic grains is suggestive of reworking in a high-energy beach or fluvial setting. Subsequently, after renewed transgression, little or no material from southern Cyprus reached the location of Site 968.

In addition, ten samples of the coarse fractions studied in thin section were subjected to whole rock X-ray diffraction (Table 1). In all cases, the dominant constituents are quartz and calcite, with minor amounts of plagioclase (albite) and dolomite, and trace amounts of chlorite, pyrite, muscovite, and smectite. Kaolinite is absent from this coarse fraction except possibly for a trace in one sample. Other constituents identified in thin sections (e.g., serpentine minerals) were presumably too low in abundance to show up in these X-ray traces. In addition, Blanc-Valleron et al. (Chap. 34, this volume) report XRD results for dark gray, interbedded clays. These are dominated by kaolinite and smectite, with minor mixed-layer clays, palygorskite, illite, and chlorite. The results also support derivation mainly from the Troodos Massif in view of the occurrence of plagioclase and smectite in particular. The kaolinite in the fine fraction was presumably derived by continental weathering of Cyprus, although a more distant origin (e.g., from the Nile River) cannot be excluded.

\section{Depositional Processes at Site 968}

Site 968 was already located in a relatively basinal setting during the Messinian. The silts and sands in the Messinian contain numerous lithoclasts of pelagic carbonate, feldspar, and igneous rock (mainly basalt and serpentinite), all derived from the Troodos ophiolite and its sedimentary cover exposed in southern Cyprus. There are three pos- sible source locations in southern Cyprus for this detrital sediment: (1) from directly onshore exposures (i.e., mainly the Miocene Pakhna Formation west of Limassol); (2) from ophiolitic and sedimentary cover units exposed northeast of Limassol (i.e., in the Limassol Forest area; Fig. 2); (3) from the main Troodos ophiolite and its cover sediments exposed further north (i.e., on the southern flanks of the Troodos Massif). The third option is favored for several reasons. First, the directly onshore Miocene exposure is dominated by pelagic carbonate (Pakhna Formation) with only very minor quartz and ophiolitic material (Eaton and Robertson, 1993). Second, derivation from the northeast can be largely discounted, in view of the existence of discrete structural highs that would have acted as barriers to sediment dispersal in the late Miocene (e.g., west-northwest to east-southeasttrending Akrotiri High; McCallum et al., 1993). By far the most important conduit for terrigenous material during the late PliocenePleistocene was the Kouris River system that drains much of the southern flanks of the Troodos Massif and reaches the coast between Limassol and the longitude of Site 968 (Fig. 2). The Kouris river system drains the southern flank of the Troodos ophiolite (including the peridotite), and its Upper Cretaceous-upper Miocene sedimentary cover (including quartzitic cherts of upper Paleocene-lower Eocene age within the Lefkara Formation). Cherts of the Lefkara Formation are the probable source of the quartzitic grains in the Messinian succession at Site 968, because quartzitic sandstone and quartzitic igneous rocks are volumetrically insignificant in potential source areas. This evidence suggests that the paleo-Kouris river system was initiated as an important sediment conduit by late Miocene time. The upper Miocene succession within the Pakhna Formation that is cut by the Kouris River includes calciturbidites containing ophiolitic and sedimentary grains (Eaton and Robertson, 1993), as seen at Site 967. Such material was shed southwards from the Troodos ophiolite in the vicinity of Mount Olymbos (Fig. 2), an area that must have been already emergent, stripped of its sedimentary cover, and actively eroding. Much of this material probably found its way offshore into a deep basin between Cyprus and the Eratosthenes Seamount during the Messinian. Coarse sediment was not recovered at Site 968, possi- 
Table 1. Mineralogical data for sand-sized fraction from the Messinian interval at Site 968.

\begin{tabular}{|c|c|c|c|c|}
\hline $\begin{array}{l}\text { Core, } \\
\text { section }\end{array}$ & $\begin{array}{c}\text { Depth } \\
(\mathrm{cm})\end{array}$ & Main minerals & Minor & Trace \\
\hline \multicolumn{5}{|l|}{ 160-968A- } \\
\hline $\begin{array}{l}32 X-4 \\
30 X-1\end{array}$ & $\begin{array}{r}64-66 \\
8-10\end{array}$ & $\begin{array}{l}\text { Calcite, quartz } \\
\text { Quartz, calcite }\end{array}$ & $\begin{array}{l}\text { Albite } \\
\text { Albite, dolomite }\end{array}$ & $\begin{array}{l}\text { Dolomite, sm } \\
\text { Chlorite }\end{array}$ \\
\hline $29 \mathrm{X}-4$ & $44-47$ & Quartz, calcite & Dolomite, albite & Chlorite \\
\hline $28 \mathrm{X}-\mathrm{CC}$ & $26-29^{+}$ & Quartz, calcite & Albite & Dolomite, chlorite \\
\hline $26 \mathrm{X}-2$ & $7-9$ & Quartz, calcite & & Dolomite, pyrite, chlorite \\
\hline $20 \mathrm{X}-1$ & $57-59^{+}$ & Quartz, calcite & Dolomite, albite & Chlorite \\
\hline $7 \mathrm{H}-3$ & $27-29^{+}$ & Calcite & Quartz & Albite, pyrite, kaolinite? chlorite, smectite* \\
\hline $4 \mathrm{H}-1$ & $79-80$ & Calcite & Quartz, albite & Chlorite \\
\hline $2 \mathrm{H}-2$ & $26-28$ & Calcite & Quartz & Albite, pyrite \\
\hline $1 \mathrm{H}-4$ & $34-36^{+}$ & Calcite, quartz & Albite & Dolomite, smectite* \\
\hline
\end{tabular}

Notes: $+=$ checked for smectite/kaolinite by glycolation and heating. ${ }^{*}=$ peak shift indicated smectite, but not found in others

bly because substantial tectonic uplift did not take place until Pliocene-Quaternary time, although it is also probable that coarse material simply bypassed the local depositional site. Such bypassing is also suggested by the absence of coarse clastic sediment in the overlying Pliocene and Pleistocene successions representing the time when southern Cyprus was being strongly uplifted (Poole and Robertson, 1991).

Shipboard studies showed that the Miocene/Pliocene boundary at Site 968 is marked by a change from relatively uniform brown silty clay and clay-rich silt with reworked nannofossils, to burrowed nannofossil clays with planktonic foraminifers of early Pliocene age (Emeis, Robertson, Richter, et al., 1996). Pierre et al. (Chap. 1, this volume) further show that (1) carbonate content increases markedly across the Messinian/Pliocene boundary; (2) there is a marked positive shift in $\delta^{18} \mathrm{O}$ values; and (3) values of $\delta^{13} \mathrm{C}$ also increase. The results indicate a change from a reduced salinity, relatively reducing, Lago Mare-type setting in the late Messinian to an open-marine, more oxidizing environment in the early Pliocene.

\section{Messinian of the Eratosthenes Seamount Sites}

Evidence of contrasting Messinian lithofacies and depositional settings was obtained by drilling a north-south traverse across the Eratosthenes Seamount south of Cyprus (Figs. 2, 3). The sites are discussed from north to south, at increasing distances from the Cyprus margin.

\section{Site 967: Lower Slope of the Eratosthenes Seamount}

Site 967 is located on a small high near the base of the lower northern slope of the seamount. Initial shipboard analysis did not reveal the presence of Messinian facies in any of the three holes drilled (Holes 967A, 967B, 967C). However, evidence of evaporites of presumed Messinian age was detected by geophysical logging and geochemical analysis in Hole 967A (Emeis, Robertson, Richter, et al., 1996), and subsequent shore-based study revealed the presence of an important Messinian/Pliocene boundary interval (Spezzaferri et al., Chap. 2, this volume). In Hole 967A recovery was absent between 120 and 125 mbsf. However, geophysical logging shows that the interval from 121 to 122 mbsf in Hole $967 \mathrm{E}$ is marked by extremely low radioactivity, high resistivity, and the density, sonic, and neutron values characteristic of an evaporite-type mineral. Formation microscanner (FMS) images show that the lower part of the interval is massive, whereas the upper shows inclined oblique lamination-like features (Emeis, Robertson, Richter, et al., 1996). Nannofossil chalk was recovered beneath the inferred evaporite (Core 160-967F-3R). The log response is interpreted to indicate the presence of gypsum interbedded with clay-rich sediments (between 115 and 122 mbsf; Emeis, Robertson, Richter, et al., 1996). In addition, concentration-depth profiles for calcium, sulfate and strontium at a depth of around 124 mbsf in Hole 967A indicate the existence of a nonchloride evaporite source for these elements, which is also interpreted as gypsum (Emeis, Robertson, Richter, et al., 1996).

Interpretation of the critical interval that includes the Messinian and the Miocene/Pliocene boundary in Hole 967A is complicated by poor recovery and extensive drilling disturbance. In Hole 967A, the lithologies recovered are mainly nannofossil ooze and chalk, with scattered chalk and ooze clasts, $<1 \mathrm{~cm}$ in size (Fig. 6).

Shipboard analysis revealed nannofossils of various ages within this interval (Cores 160-967A-16X through 13H) that were assumed to be reworked (Emeis, Robertson, Richter, et al., 1996). More detailed postcruise studies have confirmed the presence of reworked nannofossils of Eocene, Oligocene, and middle Miocene age that increase in abundance downwards (Spezzaferri et al., Chap. 2, this volume). Also, a Messinian age for this part of the succession is indicated by the presence of brackish water ostracods (i.e., Cyprideis pannonica and Loxoconca diaffarovi (Spezzaferri et al., Chap. 2, this volume), which are inferred to be in situ (i.e., Lago Mare-type facies).

Postcruise micropaleontological determinations of planktonic foraminifers and ostracods and stable isotopic analysis by Spezzaferri et al. (Chap. 2, this volume) reveals the presence of the Miocene/ Pliocene boundary at about 119 mbsf in Core 160-967A-13H (i.e., above the Lago Mare-type sediments). This core is relatively intact and comprises light-brown nannofossil ooze with scattered planktonic foraminifers that are slightly more concentrated in lighter layers (e.g., interval 160-967A-13H-2, 75-80 cm). Traces of color banding and bioturbation are also visible. A local, more yellowish horizon is marked by a relatively sharp lower boundary and a diffuse upper boundary (interval 160-967A-13H-4, 30-65 cm). This interval has a powdery texture, shown by smear-slide analysis to consist of micritic rock fragments and recrystallized calcite. The boundary unit is located in Section 160-967A-13H-3, with the first arrival of Pliocene microfossils in Section 160-967A-13H-2 (Spezzaferri et al., Chap. 2, this volume). The boundary is reflected in increases in $\delta^{18} \mathrm{O}$ and $\delta^{13} \mathrm{C}$ values (Spezzaferri et al., Chap. 2, this volume).

The overlying core of early Pliocene age (Core 160-967A-12H) is dominated by homogeneous to faintly mottled, more grayish, nannofossil ooze with thin beds $(<0.5 \mathrm{~cm})$ of foraminiferal sand, interpreted as possible calciturbidites. The following core (Core 160-967A-11H) is mainly light-colored, to reddish, to brownish nannofossil ooze with occasional foraminiferal sand-rich layers. Bioturbated layers are characterized by a reddish and yellowish color. These two cores contain normal marine benthic and planktonic foraminifers and are dated as Zanclean (earliest Pliocene) (Spezzaferri et al., Chap. 2, this volume).

A similar interval was recovered in an adjacent hole by rotary drilling (Cores 160-967E-3R through 4R) and consists mainly of greenish bioturbated nannofossil ooze with alternations of more and less foraminifer-rich bands $(\sim 5 \mathrm{~cm}$ thick). Individual foraminifer 


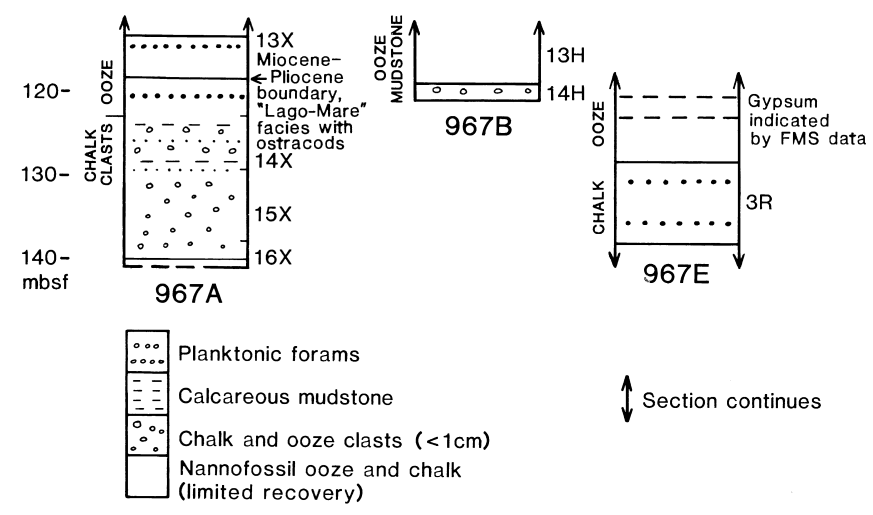

Figure 6. Details of the core recovery of the upper Miocene interval at Site 967, located on the lower slopes of the Eratosthenes Seamount. Note particularly the low-salinity, Lago Mare-type sediments between inferred Messinian gypsum and the base of the Pliocene.

shells are either empty or filled with sparry calcite. Occasional more silty horizons contain grains of apatite, silica and inorganic calcite $<3$ $\mathrm{cm}$ in size (e.g., interval 160-967E-3R-1, 10-20 cm). Traces of inclined, as well as parallel, lamination, are seen locally (Section 160967E-4R-3).

The combined shipboard and postcruise evidence suggests that, in the vicinity of Site 967 , pelagic chalks of Eocene age were originally overlain by pelagic carbonates of Oligocene and Miocene age. However, this succession was later reworked and is now represented by displaced chalky clasts in a chalky matrix; these are interpreted as low-density debris flows. It is assumed that a thin deposit $(<5 \mathrm{~m})$ of gypsum was then deposited.

If correct, the implication is that reworking as chalky debris flows took place before gypsum precipitation, possibly during the middle to late Miocene, judging by the ages of reworked nannofossils. The inferred thin gypsum layer $(<5 \mathrm{~m})$, was then overlain by uppermost Messinian Lago Mare-type sediments followed by lowermost Pliocene pelagic oozes. Elsewhere in the Western Mediterranean, the marine transgression at the end of the Messinian was marked by accumulation of brightly colored, iron-rich sediment (e.g., in the Tyrrhenian Sea; Kastens, Mascle, et al., 1990; Robertson, 1990). The color banding within the inferred Messinian-Pliocene interval in Core $160-967 \mathrm{~A}-13 \mathrm{H}$ could have a similar origin. In the Tyrrhenian Sea, this was interpreted as terrigenous iron that was reworked during the transgression at the beginning of the Pliocene.

The Messinian/Pliocene interval is overlain by pelagic oozes that show evidence of reworking, in the form of concentrations of planktonic foraminifers, silty partings, and inclined lamination. Neither evaporite nor shallow-water limestone are present in the reworked material. This rules out a source, either from the succession beneath, or from the present upper northern flank of the Eratosthenes Seamount, where Miocene shallow-water limestones were recovered at Site 965. One possibility is that reworking of local upslope areas took place associated with the Pliocene transgression, followed by pelagic carbonate deposition in the early Pliocene without further significant reworking.

\section{Site 965: Upper Slope of the Eratosthenes Seamount}

Lithofacies of inferred Messinian age were also recovered at Site 965 on the upper northern slope of the Eratosthenes Seamount (Figs. $2,3)$. The underlying succession there comprises shallow-water limestones of inferred Miocene age (lithostratigraphic Unit III; Emeis, Robertson, Richter, et al., 1996; Robertson, Chap. 33, this volume). This is abruptly overlain by $6.3 \mathrm{~m}$ of mottled calcareous clay (Core
160-965A-4H) with scattered carbonate clasts (lithostratigraphic Unit II; Emeis, Robertson, Richter, et al., 1996).

The sediment (Section 160-965A-4H-3) comprises calcareous mottled (i.e., bioturbated) mud with scattered subrounded limestone clasts up to a $1 \mathrm{~cm}$ in size. The clasts are commonly "streaked-out" vertically as a function of drilling disturbance. Some of the clasts are chalky, whereas others are more foraminifer-rich and lithified. Small $(<1 \mathrm{~cm})$ limonite concretions are rarely observed. Smear slides reveal aragonite and dolomite as small well-preserved crystals. The sediments become less indurated upward and include a 20 -cm-thick bed of unconsolidated calcareous nodules (interval 160-965A-4H-3, 92$122 \mathrm{~cm}$ ), interpreted as possible caliche. A stable isotopic analysis of one such calcareous nodule revealed relative depletion in $\delta^{13} \mathrm{C}$ and $\delta^{18} \mathrm{O}$, consistent with formation in a terrestrial setting (Böttcher et al., Chap. 29, this volume). These sediments are directly overlain by chocolate-brown clay with indurated foraminiferal sand clasts up to $0.5 \mathrm{~cm}$ in size. This clay is interpreted as a possible paleosol (Emeis, Robertson, Richter, et al., 1996). Within the interval of possible paleosol (interval 160-975A-4H-3, $125 \mathrm{~cm}$, through 4H-CC) calcareous nannofossils are only poorly preserved and calcareous nannofossils are indicative only of a late Miocene to early Pliocene age. These nannofossils include rare overgrown discoasters of probable Neogene age. There is evidence of extensive reworking, and Paleogene specimens are also present.

The evidence from Site 965 suggests that during the Messinian the present northern flank of the Eratosthenes Seamount existed as a subaerially exposed feature on which soils developed in a semiarid climate conducive to caliche development (as in southern Cyprus today; e.g., Poole and Robertson, 1991). The presence of Paleogene calcareous nannofossils suggests that part of an underlying succession was exposed to erosion in the Messinian. However, reworked Miocene shallow-water limestone was not observed, as seen beneath in Site 965 and on the Eratosthenes crestal site (Site 966). On the other hand, the succession at Site 967 on the lower Eratosthenes slope (discussed above) lacks Miocene shallow-water limestone, but includes pelagic carbonates of Oligocene, Eocene, and middle Miocene age. It is thus possible that the reworked Paleogene nannofossils were derived from the vicinity of Site 967 (i.e., somewhere to the north of Site 965), from a succession similar to Site 967 where Miocene shallow-water limestones were never deposited.

\section{Site 966: Crest of the Eratosthenes Seamount}

Additional information on Messinian paleoenvironments comes from the crestal area of the Eratosthenes Seamount at Site 966. Shallow-water limestones of Miocene age there are overlain by a distinctive matrix-supported breccias and conglomerates (23-59 m thick), with a matrix of bathyal, lower Pliocene, fine-grained sediments (Emeis, Robertson, Richter, et al., 1996; Robertson, Chap. 37, this volume). The lower part of this succession (i.e., lithostratigraphic Unit 2) contains large carbonate clasts in a micritic matrix. The clasts range from nannofossil chalk to well-lithified shallow-water limestones, similar to that of the underlying Miocene succession. In the upper part of the succession relict bedding is visible, and there is evidence of soft-sediment deformation. The existence of a matrix-supported clast-rich texture was confirmed by downhole logging, especially using the FMS. Occasional mud clasts yield calcareous nannofossils of early Pliocene age, whereas one of the clasts is provisionally dated as late Miocene. A more detailed postcruise lithostratigraphical and paleoenvironmental analysis (Robertson, Chap. 37, this volume) confirmed that this unit (termed the MassFlow Unit) was mainly deposited by debris-flow processes and was possibly shed from active fault scarps into a deepening sea in the early Pliocene. Clasts of evaporite are absent, and there is no evidence that the crest of the Eratosthenes Seamount was ever overlain by Messinian evaporites, in line with previous interpretations of seismic 
profiles (e.g., Montadert et al., 1978; Sonnenfeld and Finetti, 1985; Kempler, 1994; Krasheninnikov et al., 1994; Limonov et al., 1994; Robertson et al., 1994, 1995b, 1995c). Many of the limestone clasts are weathered and have undergone extensive diagenesis. It thus is inferred that shallow-water Miocene limestones were subaerially exposed to meteoric water diagenesis in the Messinian, followed by collapse of the seamount, accompanied by gravity reworking (Robertson, Chap. 33, this volume).

\section{COMPARISON WITH PREVIOUS DRILLING RESULTS}

An important upper Miocene succession, including $55 \mathrm{~m}$ of gypsum, was drilled on the Florence Rise on the edge of the Antalya Basin, at Sites 375 and 376 during DSDP Leg 42 (Hsü, Montadert, et al., 1978). The Florence Rise is a marked bathymetric feature running from Cyprus to the Anaximander Mountains that separates the Antalya Basin from the Levantine Basin (Fig. 2). The record was restricted to spot coring, often with poor recovery.

The recovered succession at Site 375 begins with varicolored (often reddish) nannofossil marls and subordinate foraminifer-nannofossil limestones, rich in Orbulina sp. (i.e., Units VIII-IX of Serravallian age). Interbedded graded foraminifer limestones are composed of tightly packed planktonic foraminifers and are interpreted as pelagic calciturbidites. Above this, the succession becomes more terrigenous with nannofossil marlstones, interpreted as background pelagic sediments, interbedded with graded siltstones and sandstones, interpreted as turbidites, and sapropelic layers (i.e., Unit VIITortonian). There is then an upward transition to detrital sediments containing reworked gypsum and sandy dolomitic marlstone with interbedded gypsum (i.e., Unit VI-Messinian). Gypsum facies (mainly as fragments) include massive fine-grained gypsum (alabastrinetype), fine-laminated, fine-grained gypsum (i.e., balatino-type), coarse gypsum (i.e., selenitic-type), coarse swallow-tail-type gypsum, and detrital gypsum ("gypsarenite"). Relatively shallow-water deposition is indicated by the evidence of reworking, cross bedding, and possible algal lamination. Similar gypsum facies were recovered from nearby Site 376. Overlying nannofossil-rich dolomitic marlstones at both Sites 375 and 376 are interbedded with graded sandstones and siltstones, containing reworked Cretaceous, Paleogene, and lower-upper Miocene calcareous nannofossils. (i.e., Unit V, late? Messinian). Above this, the lower Pliocene begins with nannofossil marls (Unit IV), overlain by an inferred slumped unit comprising Miocene and Pliocene sediments. Nannofossil marls of early to late Pliocene age overlie this (Unit III), followed by Pliocene-Quaternary sediments including sapropels (Units I and II). The succession on the Florence Rise (Site 376) records deep-water pelagic carbonate accumulation in the early Miocene, overlain by pelagic and turbiditic sediments, composed of sediment partly derived from ophiolites and related rocks, possibly located onshore in southern Turkey. This was followed by precipitation of evaporites (see below). The upper Miocene, evaporite-related succession on the Florence Rise was specifically compared with that of the northern part of the Mesaoria basin located between the Troodos ophiolite and the Kyrenia Range in Cyprus (Baroz et al, 1978; Pantazis, 1978). There was then further gravity input of terrigenous sediment in a lacustrine setting (Lago Mare), followed by a return to deep-marine sedimentation in the early Pliocene. Slumping in the early Pliocene was possibly triggered by tectonic movements along the Florence Rise.

Messinian evaporitic facies were also recovered elsewhere in the Mediterranean Basin during DSDP Legs 13, 42A, and Ocean Drilling Program (ODP) Leg 107. During Leg 42A (Hsü et al., 1978), gypsum-rich evaporites were recovered particularly from beneath the Ionian (Messina) Abyssal Plain (Site 374) and from the Balearic Ba$\sin$ (Site 372). Gypsum-rich facies were also cored at Sites 121, 122,
124, 125, 129, 132, 134, 371, and 378 during Leg 13 (Ryan, Hsü et al., 1973). Only general comparisons with on-land successions could be made as intact successions were not recovered.

The minor volumes of Messinian gypsum cored at Site 968 on the lower Cyprus slope can be closely compared with the upper part of the Messinian succession on the Florence Rise, as both successions are interbedded with terrigenous turbidites, rarely recorded elsewhere. In more detail, this interval at Site 376 (Unit V; Cores 7-15) is about $85 \mathrm{~m}$ thick and shows an overall fining-upward succession, comprising marlstones interbedded with turbiditic siltstones and sandstones, often composed of detrital gypsum ("gypsarenite"). Clastic units become finer grained and less abundant upward. Dolomite is locally abundant, and clay minerals are mainly chlorite, attapulgite, and smectite. Colors are subdued and plant material is locally abundant. A 5-cm-thick layer of coarsely crystalline, white gypsum in the lower part of the succession was interpreted as either "a layer, nodule, or two redeposited cobbles." In addition, large gypsum crystals of inferred diagenetic origin are locally present.

Both the Cyprus margin and the Florence Rise are located along the present-day active Cyprus margin (i.e., "Cyprus arc"). Both sites were located in a deep-water, basinal setting during the Messinian, receiving input of terrigenous turbiditic sediments, mainly from southern Cyprus at Site 968, and possibly from southern Turkey at DSDP Sites 375 and 376. An overall lacustrine, Lago Mare-type depositional setting is inferred in both cases. At Site 376, evaporites (mainly gypsum, but also including halite) were cored beneath the Lago Mare-type facies, and pore fluid geochemical data also suggest that gypsum is present beneath the cored interval at Site 968 (Emeis, Robertson, Richter, et al., 1996).

Somewhat similar facies of Lago Mare-type sediments were recovered from the upper part of the Messinian succession in the Ionian Sea, and comprise dolomitic mud and mudstone, with no preserved infaunal fossils. In contrast to Sites 376 and 968 , turbidites are not present, perhaps reflecting a relatively distal depositional setting.

Lacustrine-type Messinian sediments were also drilled in the Tyrrhenian Sea during Leg 107 (Kastens, Mascle, et al., 1990; Robertson et al., 1990). The Messinian there comprises alternations of terrigenous muds and silts with scattered sulfate nodules. These sediments accumulated in an unstable, rift-related, tectonic setting contemporaneously with deeper-water accumulation of mainly fine-grained gypsum in an adjacent fault-controlled basin further west (Site 652). In contrast, however, to Sites 652 and 968, a shallow lacustrine, rather than a deep basinal setting is envisioned. On-land examples of Lago Mare-type facies include part of the upper Miocene of Italy (Ricci Lucchi, 1973; Schreiber et al., 1976, 1986) and within some facies in southwestern Cyprus (Orszag-Sperber et al., 1989). Evaporites recovered at other sites during Leg 42A (Sites 371, 372, and 378) comprise more heterogeneous gypsum facies (e.g., both fine and coarse), as do widely exposed successions on land around the margins of the Mediterranean basin (e.g., in Cyprus, see below).

\section{COMPARISON WITH CYPRUS, ONSHORE AND OFFSHORE}

The inferred Messinian succession cored at Site 968 can be compared with the upper Miocene succession of southern Cyprus and offshore areas. There are no seismic data to link Site 968 directly upslope with onshore Cyprus. However, a north-south multichannel seismic profile located about $40 \mathrm{~km}$ to the east (east of the Akrotiri Peninsula; Fig. 2) can be linked with shallow-penetration singlechannel seismic coverage of the shelf and upper slope areas to produce an overall picture of the seismic facies structure off southern Cyprus (McCallum et al., 1993). The multichannel seismic data reveal that a nearly undeformed inferred Pliocene-Quaternary succession underlain by a pronounced reflector that is interpreted as the top 
of the Messinian. This reflector can be correlated with other seismic data for offshore southern Cyprus (Reflector "A" of Woodside, 1977; reflector M of Ryan, 1978) and also with Sites 375 and 376 west of Cyprus. Little structure is visible beneath this in the south Cyprus data. However, a lower reflector is interpreted as the base of the Messinian, and a further reflector beneath this can be correlated with a structural high extending onshore in the Akrotiri Peninsula (i.e., Akrotiri High of McCallum et al., 1993; Fig. 2). Good quality single-channel TREDMAR seismic date, in addition to earlier seismic studies, indicate that no well-defined "M" reflector is present within the deep basin (i.e., "Northern Basin") between southern Cyprus and the Eratosthenes Seamount, implying that thick Messinian evaporites were not deposited there (Kempler, 1994; Limonov et al., 1994; Robertson et al., 1995b). The "M" reflector is, however, well-imaged around the southern, western, and eastern margins of the seamount and inferred thicknesses of Messinian reach 1500-2000 m thick in adjacent basins. The inferred evaporite is seen to pinch out against the upper slopes of the Eratosthenes Seamount, except along the northern margin where evaporite is not seismically imaged. Messinian evaporites are also imaged beneath the southern flank of the seamount and dip beneath the "Southern Basin" that is inferred to be filled with Pliocene-Pleistocene sediments (Limonov et al., 1994; Robertson et al., 1995b).

The onshore Miocene geology of southern Cyprus is dominated by pelagic and hemipelagic carbonates of the Pakhna Formation. Coral reefs developed mainly around the margins of the Troodos ophiolite to the north and shed shallow-water-derived sediment into deeper water basinal areas to the south (Eaton and Robertson, 1993; Robertson et al., 1991). Several sub-basins (i.e., Maroni sub-basin in the east and Khalassa sub-basin in the west, Fig. 2) were separated by structural highs, including the Akrotiri High, an important westnorthwest to east-southeast-trending feature located beneath the Akrotiri Peninsula and adjacent offshore areas to the east. In general gypsum is best exposed in southern Cyprus in the Maroni sub-basin, east of Limassol (Fig. 2). The depocenter of this evaporitic basin was probably located a short distance offshore, based on thickness variations. West of Limassol only the northern margins of an original evaporite basin are now preserved (i.e., Khalassa sub-basin, Fig. 2). Evaporite is again exposed further west, in the Pissouri sub-basin, and more extensively in the Polemi sub-basin further northwest.

During the Messinian sea-level dropped within the sub-basins on Cyprus, giving rise, first, to accumulation of hemipelagic marls and laminated diatomaceous sediments ("pre-evaporitic facies"; OrszagSperber et al., 1989). This was followed by accumulation of gypsum. Facies analysis indicates that fine-grained (i.e., balatino-type) gypsum accumulated near the centers of the sub-basins, whereas coarse selenitic-type gypsum accumulated in more marginal areas (Robertson et al., 1995a). Selenitic gypsum was locally redeposited toward the basin depocenters by turbiditic and debris flow processes (e.g., in the Maroni sub-basin). Water depths were probably less than tens of meters deep, even near depocenters. The selenitic gypsum accumulated in very shallow to emergent settings (i.e., in marginal salinas). Throughout southern and western Cyprus, basinal mainly finegrained gypsum is overlain by a chaotic unit composed of a gypsum "mega-breccia" up to several tens of meters thick (Fig. 3). This unit is inferred to have formed by large-scale sliding of gypsum, mainly formed near the basin margins, toward the depocenters of individual sub-basins (Robertson et al., 1995a). In southern Cyprus, the gypsum is commonly affected by normal faulting that appears to date from the late Messinian and/or earliest Pliocene, as the overlying PliocenePleistocene successions show little evidence of faulting.

In the Pissouri sub-basin, in southwest Cyprus, the gypsum is overlain by a nonmarine unit of lacustrine, fluvial and paleosol deposits dated by Rouchy et al. (1980) as late Messinian in age. More recent facies analysis indicates that a series of small fan-deltaic clastic sediments prograded over a narrow basin margin area, where pa- leosols developed. The marginal facies then pass northward into gypsum near the basin depocenter (Robertson et al., 1995a).

In southern Cyprus, the Messinian gypsum is directly overlain by lower Pliocene mudstones and siltstones in the Maroni sub-basin, with a well-preserved macrofauna (e.g,. large bivalves) and microfauna, including ostracods and planktonic foraminifers (McCallum, 1990). Upward, there is then an abrupt change to much coarser facies composed of marine channelized conglomerates, including clasts derived from the Troodos ophiolite and its overlying Tertiary sedimentary succession. These conglomerates are then overlain by a range of nonmarine Pleistocene deposits, including caliche, eolian sands, fluvial conglomerates and paleosols (Poole and Robertson, 1991).

The on-land sedimentary successions of southern Cyprus are interpreted in terms of bathyal pelagic accumulation until the Miocene, followed by localized tectonic uplift (i.e., in areas north of Limassol). This uplift was related to compressional deformation in the early Miocene and gave rise to a series of west-northwest to east-southeast-trending sub-basins (e.g., Maroni, Khalassa) in which heterogeneous marine carbonate facies of the Pakhna Formation accumulated (Eaton and Robertson, 1993). Gypsum then accumulated during the Messinian. Extensional faulting took place in many areas of southern Cyprus during the late Miocene, and in southern Cyprus (i.e., the Maroni sub-basin) the Messinian gypsum is cut by numerous extensional faults.

The range of gypsum facies on land is generally similar to those encountered by drilling during DSDP Legs 13 and 42A and ODP Leg 107 (e.g., finely laminated gypsum, coarse selenitic gypsum). However, the evaporites recovered by drilling were precipitated far below eustatic sea level, as shown by the presence of directly overlying deep-water, lower Pliocene, nannofossil-rich oozes. The evaporites of southern Cyprus are underlain by lower and upper Miocene, shallow-water, coral-reef limestones, the Terra and Koronia Members, respectively, of the Pakhna Formation (Follows et al., 1996). The evaporites are then overlain by relatively shallow-marine lower Pliocene terrigenous muds. An exception is the area between the Troodos ophiolite and the Kyrenia Range to the north in which the upper Miocene succession includes local halite that was encountered in boreholes (Bear, 1960). This halite was precipitated in what was then still a deep-marine basin (i.e., Mesaoria basin).

\section{MESSINIAN PALEOENVIRONMENTS AND TECTONIC SETTING}

Sufficient information exits from Site 968 and onshore Cyprus, the Eratosthenes Seamount sites (Sites 965, 966, and 967) and from the Florence Rise (Site 376) to infer the regional late Miocene-early Pliocene paleobathymetry of this region (Fig. 7).

Site 968 was located in a basinal setting of reduced (but possibly variable) salinity (i.e., of Lago Mare-type), which was probably mainly anoxic, and received turbiditic input derived by erosion of lithologies exposed in southern Cyprus (e.g., pelagic limestone, ophiolite). Interbedded gypsum is assumed to be detrital. A deep basin existed between southern Cyprus and the Eratosthenes Seamount during the latest Miocene, in which Lago Mare-type facies accumulated. Southern Cyprus was already uplifted to near, or above, sea level by the early Miocene, and thus the onshore Messinian evaporites accumulated not far below eustatic sea level. Lacustrine and fluvial deposition, with soil development, were locally established in southwestern Cyprus in the latest Messinian (i.e., in the Pissouri sub-basin). The pore-water geochemical data from Site 968 support the presence of at least some Messinian evaporite on the lower part of the slope south of Cyprus. However, seismic data do not support the existence of thick evaporites further south in the basin located between Cyprus and the Eratosthenes Seamount. Evaporites were possibly deposited in the, then, deep basin, but, if so, were later underthrust beneath $\mathrm{Cy}$ - 

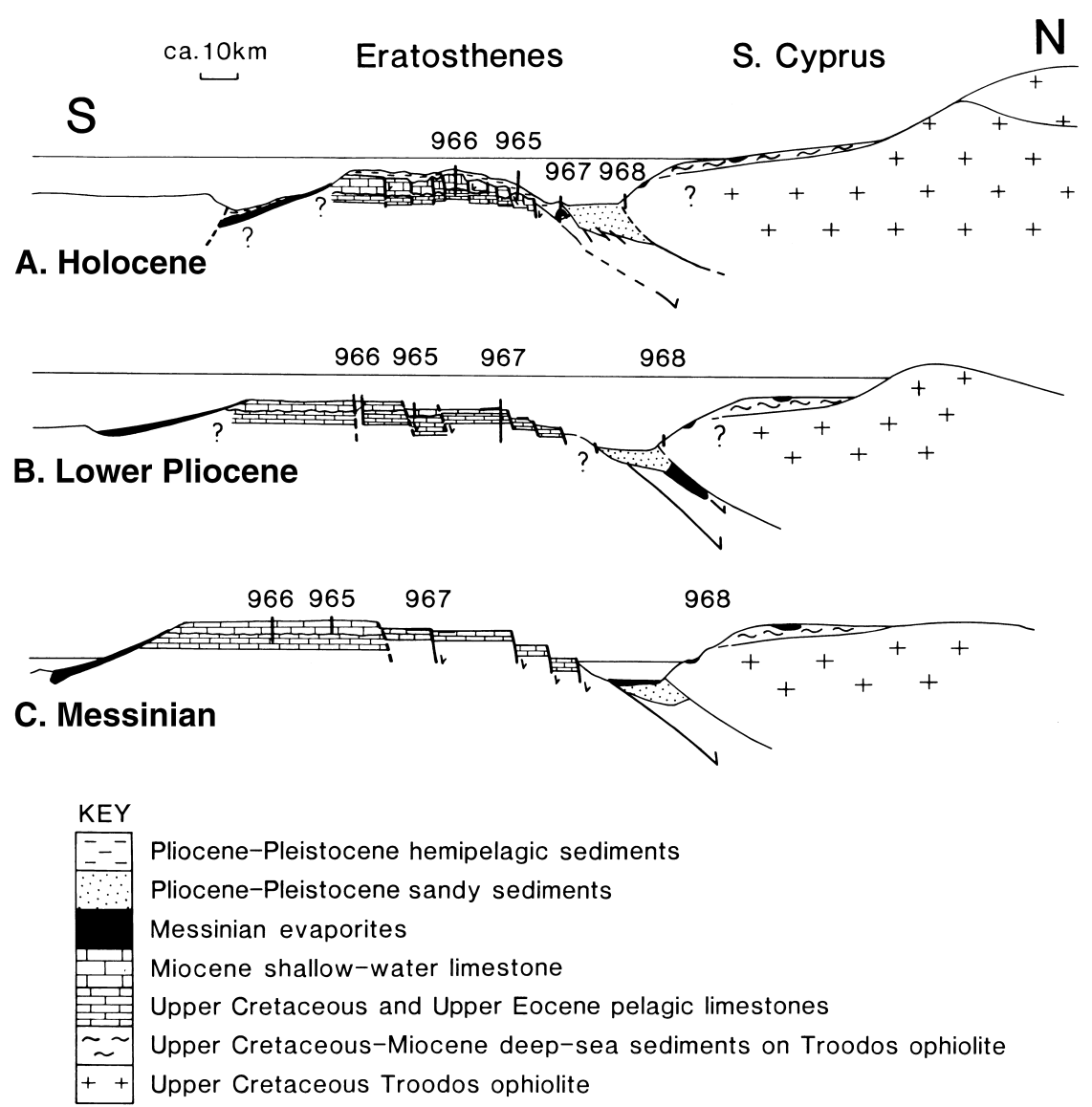

Figure 7. Inferred paleoenvironments and tectonic evolution of the Eratosthenes Seamount in relation to southern Cyprus, based on sites drilled and geophysically logged during Leg 160. The Eratosthenes Seamount is inferred to be a continental fragment adjacent to the African Plate that converged on the Eurasian Plate during Neogene to Holocene time in response to northward subduction. A. Messinian: the seamount was free of evaporite precipitation, but gypsum accumulated locally at Site 967. Gypsum also precipitated in small structurally controlled sub-basins onshore in southern Cyprus. B. Pliocene: The Eratosthenes Seamount subsided as it entered the subduction-related trench to the north. C. Holocene: The seamount is at an advanced stage of subsidence and fault breakup related to underthrusting beneath southern Cyprus.

prus, related to subduction and collision of the Eratosthenes Seamount.

During the Messinian, the present northern upper slope of the seamount (Site 965) was exposed to erosion, soil and caliche development, with input of reworked calcareous nannofossils, possibly from the north. On the crest of the seamount (Site 966), Miocene shallowwater limestones were subaerially exposed and flushed by meteoric waters. The area making up the present lower slopes of the seamount (Site 967) underwent reworking of Eocene, Oligocene, and Miocene pelagic biota, derived from a short distance up paleoslope. This was followed by minor $(<5 \mathrm{~m})$ gypsum precipitation, possibly in a small silled basin adjacent to a deeper basin to the north, and then by upper Messinian, Lago Mare-type facies. Marine transgression was marked by a sudden increase in paleosalinity as indicated by stable isotopic evidence (Spezzaferri et al., Chap. 2, this volume) and the accumulation of reddish ferruginous sediment, possibly reworked from an oxidized Messinian land surface.

Possible explanations for the apparent lack of seismically imaged evaporites in the basin between Cyprus and the Eratosthenes Seamount are as follows: (1) This area then formed a raised part of the Eratosthenes Seamount on which evaporites were never deposited, but which then broke up and subsided in the Pliocene-Quaternary related to underthrusting beneath Cyprus (Robertson et al., 1995b, 1995c). (2) The basinal sediments were mainly terrigenous, similar to those of Site 968, rather than evaporites.
The absence of shallow-water limestones at Site 967 on the lower Eratosthenes slope, in contrast to the Eratosthenes upper slope and crestal sites (Sites 965 and 966), shows that Site 967 cannot simply be considered as a former northward extension of the Eratosthenes Seamount plateau area. On the other hand, pelagic limestones of $\mathrm{Pa}-$ leogene age are present at both Sites 967 and 966, suggesting the existence of a lateral continuity of depositional settings before the Miocene. It is possible that Site 967 was located on crust that formed a morphological northward extension of the Eratosthenes Seamount before the Miocene. This area did not undergo uplift in the Miocene and resulting deposition of shallow-water limestones (Sites 965 and 966), but instead remained in a deep-water setting. Eocene, Oligocene, and Miocene pelagic successions accumulated in the vicinity of Site 967. Probably during the Miocene (before or during the Messinian), Site 967 underwent tectonic instability, possibly involving uplift, and the inferred Oligocene-Miocene succession was reworked as chalky debris flows. Tectonic movement may have continued in the Messinian to produce a small-silled basin, in which gypsum accumulated. This gypsum is unlikely to represent the margin of a thicker evaporite deposit, as gypsum is not detected seismically either to the north or south. A low-salinity setting, probably a large lake, developed in the late Messinian. The sea then flooded into what was by then already a relatively deep basin, in contrast to the other Eratosthenes sites $(965,966)$, where lower Pliocene bathyal sediments overlie Miocene shallow-water limestones. Further deepening took 
place in late Pliocene-early Pleistocene time. The facies evidence thus points to Site 967, at the base of the Eratosthenes slope, as having a complex, long-lived history of differential tectonic movements. Some of this displacement apparently took place before, during, and soon after late Miocene time. Site 967 was reactivated by compressional deformation in late Pleistocene to Holocene time to produce the present folded structure, related to collision of the Eratosthenes Seamount with the Cyprus active margin.

\section{CONCLUSIONS}

1. Site 968 on the lower slope of the Cyprus margin records the accumulation of reducing muds and minor redeposited gypsum, interbedded with turbiditic silts and sands derived from southern Cyprus during Messinian time. Provenance was from the Troodos ophiolite and its sedimentary cover, particularly Miocene pelagic carbonates (Pakhna Formation) and underlying Paleogene chertbearing successions (Lefkara Formation).

2. Messinian sediments at Site 968 accumulated in an inland sea or large lake (i.e., Lago Mare-type facies), as suggested by the absence of a coeval marine biota and the presence of minor volumes of fine-grained gypsum. The gypsum is silty and impure, in contrast to fine-grained (i.e., alabastrine) gypsum onshore in southern and western Cyprus. Local redeposition of gypsum (i.e., as gypsiferous sandstone) took place at Site 968.

3. In the Messinian, the crestal and upper slope sites of the Eratosthenes Seamount (Sites 966 and 965) were located on a paleotopographic high above the level of precipitation of Messinian evaporites. This confirms interpretations of seismic profiles that indicate that the evaporites pinch out against the upper southern, western, and eastern slopes of the seamount. Paleosols, with caliche, accumulated on the upper slope site (Site 965), while Miocene limestones on the crestal site (Site 966) were subaerially exposed.

4. The nature of the cored Messinian facies, combined with seismic evidence, suggest that a deep basin was already in existence between the Eratosthenes Seamount and southern Cyprus. Site 967, on the present lower slopes of the seamount, was probably then located near the southern edge of this basin. Relatively coarse clastic sediment was able to reach this area in the Messinian, but the site was bypassed by coarse clastic sediment during the later Pliocene-Pleistocene uplift of southern Cyprus.

5. The present, lower, northern Eratosthenes slope (Site 967) underwent important tectonic displacement, possibly involving extensional faulting before, during, and soon after the late Miocene. Eocene, Oligocene, and Miocene pelagic carbonate, now represented by reworked planktonic biota, were reworked as chalky debris flows, probably before the Messinian. Thin $(<5 \mathrm{~m})$ inferred gypsum possibly accumulated in a small, tectonically controlled basin, as in southern Cyprus. The area later subsided strongly, notably in late Pliocene-early Pleistocene time.

6. Postcruise studies have revealed the presence of a well-preserved Messinian/Pliocene boundary succession at Site 967 (Spezzaferri et al., Chap. 2, this volume). Associated reddish banded, finegrained, calcareous sediments may reflect input of iron oxide from the Messinian land surface, as recorded at ODP sites in the Tyrrhenian Sea, Western Mediterranean.

7. The depositional processes and paleoenvironments of the late Messinian? successions at Sites 968, 365, and 366 on the Florence Rise are very similar, both involving input of terrestrially derived turbidites into a basinal setting. The Eratosthenes Seamount shows evidence of subsidence and tectonic breakup in the early Pliocene-Pleistocene, whereas the Florence Rise underwent slumping of Miocene and Pliocene sediments in the early Pliocene, probably related to tectonic instability. Events in both these areas record subduction and incipient collision along the $\mathrm{Cy}$ prus active margin.

\section{ACKNOWLEDGMENTS}

The author thanks Diana Baty for assistance with drafting of figures and Yvonne Cooper for photography. The manuscript benefited from comments by Judith McKenzie and Zvi Garfunkel.

\section{REFERENCES}

Baroz, F., Bizon, G., Bizon, J.-J., Heimann, K.O., Mallet, J.-P., Muller, C., Orszag-Sperber, F., Rouchy, J.-M., and Weisgerber, F., 1978. Le Miocéne terminal et le Pliocéne dans la région de Polemi (Chypre Ouest): milieux de dépot. C.R. Acad. Sci. Ser. 2, 286:1771-1774.

Bear, L.M., 1960. The geology and mineral resources of the Akaki-Lythrondondha area. Mem. Cyprus Geol. Surv. Dep., 3.

Eaton, S., and Robertson, A.H.F., 1993. The Miocene Pakhna Formation, Cyprus, and its relationship to the Neogene tectonic evolution of the Eastern Mediterranean. Sediment. Geol. 86:273-296.

Emeis, K.-C., Robertson, A.H.F., Richter, C., et al., 1996. Proc. ODP, Init. Repts., 160: College Station, TX (Ocean Drilling Program).

Follows, E.J., Robertson, A.H.F., and Scoffin, T.P., 1996. Tectonic controls of Miocene reefs and related carbonate facies in Cyprus. In Fransen, E.K., Esteban, M., Ward, W.C., and Rouchy, J.-M. (Eds.), Models for Carbonate Stratigraphy from Miocene Reef Complexes of Mediterranean Regions. Concepts Sedimentol. Paleontol., 5: 295-316.

Hsü, K.J., Montadert, L., Bernoulli, D., Cita, M.B., Erickson, A., Garrison, R.E., Kidd, R.B., Melières, F., Müller, C., and Wright, R., 1978. History of the Mediterranean salinity crisis. In Hsü, K.J., Montadert, L., et al., Init. Repts. DSDP, 42 (Pt. 1): Washington (U.S. Govt. Printing Office), 1053-1078.

Hsü, K.J., Montadert, L., et al., 1978. Init. Repts. DSDP, 42 (Pt. 1): Washington (U.S. Govt. Printing Office).

Hsü, K.J., Ryan, W.B.F., and Cita, M.B., 1973. Late Miocene desiccation of the Mediterranean Sea. Nature, 242:240-244.

Kastens, K.A., Mascle, J., et al., 1990. Proc. ODP, Sci. Results, 107: College Station, TX (Ocean Drilling Program).

Kempler, D., 1994. Tectonic patterns in the easternmost Mediterranean [Ph.D. thesis]. Hebrew Univ.

Krasheninnikov, V.A., Udintsev, G.B., Mouraviov, V., and Hall, J.K., 1994 Geological structure of the Eratosthenes Seamount. In Krasheninnikov, V.A., and Hall, J.K. (Eds.), Geological Structure of the Northeastern Mediterranean (Cruise 5 of the Research Vessel Akademik Nokolaj Strakhov): Jerusalem (Historical Productions-Hall Ltd.), 113-130.

Limonov, A.F., Woodside, J.M., and Ivanov, M.K. (Eds.), 1994. Mud Volcanism in the Mediterranean and Black Seas and Shallow Structure of the Eratosthenes Seamount. Initial Results of the Geological and Geophysical Investigations during the Third "Training-through-Research" Cruise of the $R / V$ Gelendzhik (June-July 1993). UNESCO Rep. Mar. Sci., 64.

McCallum, J.R., 1990. Sedimentation and tectonics of the Plio-Pleistocene of Cyprus [Ph.D. thesis]. Univ. of Edinburgh.

McCallum, J.R., Scrutton, R.A., Robertson, A.H.F., and Ferrari, W., 1993. Seismostratigraphy and Neogene-Recent depositional history of the south-central continental margin of Cyprus. Mar. Petrol. Geol., 10:426438.

Montadert, L., Letouzey, J., and Mauffret, A., 1978. Messinian event: seismic evidence. In Hsü, K.J., Montadert, L., et al., Init. Repts. DSDP, 42 (Pt. 1): Washington (U.S. Govt. Printing Office), 1037-1050.

Orszag-Sperber, F., Rouchy, J.-M., and Elion, P., 1989. The sedimentary expression of regional tectonic events during the Miocene Pliocene transition in the southern Cyprus basins. Geol. Mag., 126:291-299.

Pantazis, T.M., 1978. Cyprus. In Ross, D.A., Neprochnov, Y.P., et al., Init. Repts. DSDP, 42 (Pt. 2): Washington (U.S. Govt. Printing Office), 11851194.

Poole, A.J., and Robertson, A.H.F., 1991. Quaternary uplift and sea-level change at an active plate boundary, Cyprus. J. Geol. Soc. Lond., 48:909921.

Ricci-Lucchi, R., 1973. Residemented evaporites: indicators of slope instability and deep basin conditions in Peri-Adriatic Messinian (Apennines 
foredeep, Italy). In Drooger, C.W. (Ed.), Messinian Events in the Mediterranean: Amsterdam (North Holland Press), 142-149.

Robertson, A.H.F., 1977. The origin and diagenesis of cherts from Cyprus. Sedimentology, 24:11-30.

, 1990. Geochemistry and mineralogy of iron- and trace-metal-rich Messinian and Pliocene mudstones cored on the Sardinian Margin: ODP Leg 107, Tyrrhenian Sea (Central Mediterranean). In Kastens, K.A., Mascle, J., et al., Proc. ODP, Sci. Results, 107: College Station, TX (Ocean Drilling Program), 245-253.

Robertson, A.H.F., Eaton, S., Follows, E.J., and McCallum, J.E., 1991. The role of local tectonics versus global sea-level change in the Neogene evolution of the Cyprus active margin. In Macdonald, D.I.M. (Ed.), Sedimentation, Tectonics and Eustacy Sea-level Changes at Active Margins. Spec. Publ. Int. Assoc. Sedimentol., 12:331-369.

Robertson, A.H.F., Eaton, S.E., Follows, E.J., and Payne, A.S., 1995a. Sedimentology and depositional processes of Miocene evaporites from Cyprus. Terra Nova, 7:233-254.

Robertson, A.H.F., Hieke, W., Mascle, G., McCoy, F., McKenzie, J., Rehault, J.P., and Sartori, R., 1990. Summary and synthesis of the Tyrrhenian Sea, Western Mediterranean: Leg 107 of the Ocean Drilling Program. In Kastens, K.A., Mascle, J., et al., Proc. ODP, Sci. Results, 107: College Station, TX (Ocean Drilling Program), 636-688.

Robertson, A.H.F., Kidd, R.B., Ivanov, M.K., Limonov, A.F., Woodside, J.M., Galindo-Zaldivar, J., and Nieto, L., 1994. Probing continental collision in the Mediterranean Sea. Eos, 75:233, 239.

Robertson, A.H.F., Kidd, R.B., Ivanov, M.K., Limonov, A.F., Woodside, J.M., Galindo-Zaldivar, J., Nieto, L., and the Scientific Party of the 1993 TTR-3 Cruise, 1995b. Eratosthenes Seamount, easternmost Mediterranean: evidence of active collapse and underthrusting beneath the Cyprus active margin. Terra Nova, 7:254-264.

Robertson, A.H.F., and the Scientific Party of Leg 160, 1995c. Evidence of collisional processes associated with ophiolite obduction in the Eastern
Mediterranean: results of Ocean Drilling Program Leg 160. GSA Today, 5:213.

Rouchy, J.-M., Orszag-Sperber, F., Bizon, G., and Bizon, J.-J., 1980. Mise en évidence d'une phase d'émersion fini-messinienne dans le bassin de Pissouri (Chypre): une modalité de passage Miocene-Pliocene en Méditerranée orientale. C. R. Acad. Sci. Ser. 2, 291:729-732.

Rouchy, J.-M., and Saint Martin, J.-P., 1992. Late Miocene events in the Mediterranean as recorded by carbonate evaporite relations. Geology, 20:629-632.

Ryan, W.B.F., 1978. Messinian badlands on the southeastern margin of the Mediterranean Sea. Mar. Geol., 27:349-363.

Ryan, W.B.F., Hsü, K.J., et al., 1973. Init. Repts. DSDP, 13 (Pts. 1 and 2): Washington (U.S. Govt. Printing Office).

Schreiber, B.C., Friedman, G.M., Decima, A., and Schreiber, E., 1976. Depositional environments of Upper Miocene (Messinian) evaporite deposits of the Sicilian basin. Sedimentology, 23:729-760.

Schreiber, B.C., Tucker, M.E., and Till, R., 1986. Arid shorelines and evaporites. In Reading, H. (Ed.), Sedimentary Environments and Facies (2nd ed.): Oxford (Blackwell Sci. Publ.), 189-228.

Sonnenfeld, P., and Finetti, I., 1985. Messinian evaporites in the Mediterranean: a model of continuous inflow and outflow. In Stanley, D.J., and Wezel, F.-C. (Eds.), Geological Evolution of the Mediterranean Basin: New York (Springer-Verlag), 347-353.

Woodside, J.M., 1977. Tectonic elements and crust of the eastern Mediterranean Sea. Mar. Geophys. Res., 3:317-354.

Date of initial receipt: 6 January 1997

Date of acceptance: 20 August 1997

Ms 160SR-037 